\title{
Efficacy of chlorhexidine rinses after periodontal or implant surgery: a systematic review
}

\author{
Solderer, Alex ; Kaufmann, Manuela ; Hofer, Deborah ; Wiedemeier, Daniel ; Attin, Thomas ; Schmidlin, Patrick
} $\mathrm{R}$

\begin{abstract}
BACKGROUND: Biofilm management and infection control are essential after periodontal and implant surgery. In this context, chlorhexidine (CHX) mouth-rinses are frequently recommended post-surgically. Despite its common use and many studies in this field, a systematic evaluation of the benefits after periodontal or implant surgery is-surprisingly-still missing. OBJECTIVES: To evaluate the benefits of chlorhexidine rinsing after periodontal or implant surgery in terms of plaque and inflammation reduction potential. Furthermore, to screen whether the concentration changes or additives in $\mathrm{CHX}$ solutions reduce side effects associated with its use. MATERIALS AND METHODS: A systematic literature search was performed for clinical trials, which compared CHX rinsing after periodontal or implant surgery with rinsing using placebo, non-staining formulations, or solutions with reduced concentrations of the active compound. Four databases (Medline, PubMed, Embase, Cochrane) were searched up to June 2018. Two reviewers independently identified and screened the literature. RESULTS: From 691 titles identified, only eleven publications met the inclusion criteria and were finally included. Mainly early publications assessed the benefits of $\mathrm{CHX}$ over placebo rinsing, whereas more recent publications focused more on the evaluation of new formulations with regard to effectiveness and side effects. The use of CHX after surgery showed in general significant reduction in plaque (means of $29-86 \%$ after 1 week) and bleeding (up to 73\%) as compared to placebo. No consensus, however, was found regarding the most beneficial CHX formulation avoiding side effects. CONCLUSION: Chlorhexidine rinsing helps to reduce biofilm formation and gingival inflammation after surgery. However, no additional reduction of periodontal probing depth over any given placebo or control solution could be found irrespective of whether CHX was used or not. The use of additives such as antidiscoloration systems (ADS) or herbal extracts may reduce side effects while retaining efficacy. CLINICAL RELEVANCE: Within the limitations of this review, it can be concluded that CHX may represent a valuable chemo-preventive tool immediately after surgery, during the time period in which oral hygiene capacity is compromised. To reduce the side effects of $\mathrm{CHX}$ and maintain comparable clinical effects, rinsing with less concentrated formulations (e.g., $0.12 \%$ ) showed the most promising results so far.
\end{abstract}

DOI: https://doi.org/10.1007/s00784-018-2761-y

Posted at the Zurich Open Repository and Archive, University of Zurich

ZORA URL: https://doi.org/10.5167/uzh-167430

Journal Article

Accepted Version

Originally published at:

Solderer, Alex; Kaufmann, Manuela; Hofer, Deborah; Wiedemeier, Daniel; Attin, Thomas; Schmidlin, Patrick R (2019). Efficacy of chlorhexidine rinses after periodontal or implant surgery: a systematic review. Clinical Oral Investigations, 23(1):21-32. 
DOI: https://doi.org/10.1007/s00784-018-2761-y 


\title{
Efficacy of chlorhexidine rinses after periodontal or implant surgery: A systematic review
}

\author{
Solderer $\mathrm{A}^{1}$, Kaufmann $\mathrm{M}^{1}$, Hofer $\mathrm{D}^{1}$, Wiedemeier $\mathrm{D}^{2}$, Attin $\mathrm{T}^{1}$, Schmidlin $\mathrm{PR}^{1}$ \\ 1 Clinic of Preventive Dentistry, Periodontology and Cariology, Center of Dental \\ Medicine, University of Zurich, Plattenstrasse 11, 8032, Zurich, Switzerland. \\ 2 Statistical Services, Center of Dental Medicine, University of Zurich, Switzerland
}

\begin{abstract}
Alex Solderer
Alex.solderer@zzm.uzh.ch

Manuela Kaufmann

Manuela.kaumann@zzm.uzh.ch

Deborah Hofer

Deborah.hofer@zzm.uzh.ch

Daniel Wiedemeier

Daniel.wiedemeier@zzm.uzh.ch
\end{abstract}

Thomas Attin

Thomas.attin@zzm.uzh.ch

Patrick Schmidlin

Patrick.schmidlin@zzm.uzh.ch 


\section{Compliance with Ethical Standards}

Conflict of Interest: Author Alex Solderer declares that he has no conflict of interest. Author Manuela Kaufmann declares that he has no conflict of interest. Author Deborah Hofer declares that he has no conflict of interest. Author Daniel Wiedemeier declares that he has no conflict of interest. Author Thomas Attin declares that he has no conflict of interest. Author Patrick Schmidlin declares that he has no conflict of interest.

Funding: The work was supported by the Clinic of Preventive Dentistry, Periodontology and Cariology, Center of Dental Medicine, University of Zurich. / No Funding

Ethical approval: This article does not contain any studies with human participants or animals performed by any of the authors.

Informed consent: For this type of study, formal consent is not required. 


\section{Abstract}

Background: Biofilm management and infection control are essential after periodontal and implant surgery. In this context, chlorhexidine ( $\mathrm{CHX}$ ) mouth-rinses are frequently recommended post-surgically. Despite its common use and many studies in this field, a systematic evaluation of the benefits after periodontal or implant surgery is - surprisingly - still missing.

Objectives: To evaluate the benefits of chlorhexidine rinsing after periodontal or implant surgery in terms of plaque and inflammation reduction potential. Furthermore, to screen whether the concentration changes or additives in $\mathrm{CHX}$ solutions reduce side effects associated with its use. Materials and Methods: A systematic literature search was performed for clinical trials, which compared $\mathrm{CHX}$ rinsing after periodontal or implant surgery with rinsing using a placebo, nonstaining formulations or solutions with reduced concentrations of the active compound. Four databases (Medline, Pubmed, Embase, Cochrane) were searched up to June 2018. Two reviewers independently identified and screened the literature.

Results: From 691 titles identified, only eleven publications met the inclusion criteria and were finally included. Mainly early publications assessed the benefits of $\mathrm{CHX}$ over placebo rinsing, whereas more recent publications focused more on the evaluation of new formulations with regard to effectiveness and side effects. The use of $\mathrm{CHX}$ after surgery showed in general significant reduction in plaque (means of $29-86 \%$ after 1 week) and bleeding (up to $73 \%$ ) as compared to placebo. No consensus, however, was found regarding the most beneficial $\mathrm{CHX}$ formulation avoiding side-effects.

Conclusion: Chlorhexidine rinsing helps to reduce biofilm formation and gingival inflammation after surgery. However, no additional reduction of PPD over any given placebo or control solution could be found irrespective whether $\mathrm{CHX}$ was used or not. The use of additives such as anti-discoloration systems (ADS) or herbal extracts may reduce side effects while retaining efficacy.

Clinical relevance: Within the limitations of this review, it can be concluded that $\mathrm{CHX}$ may represents a valuable chemo-preventive tool immediately after surgery, during the time period in which oral hygiene capacity is compromised. To reduce the side effects of $\mathrm{CHX}$ and maintain comparable clinical effects, rinsing with less concentrated formulations (e.g. $0.12 \%$ ) showed the most promising results so far.

Keywords: Chlorhexidine - Periodontitis - Dental implant - Mouthwashes 


\section{Introduction}

Oral biofilms are the main etiologic factor for the development of periodontitis and peri-implantitis [1]. In addition, wound healing after periodontal and implant surgery may be negatively affected

by the presence of such biofilms [1]. Hence, a reduction or better elimination of biofilm is essential for restoring gingival tissues to a healthy state [1]. Especially after surgical interventions, plaque control by mechanical means is restricted and therefore must be achieved using other measures, such as antimicrobial strategies [2]. In this regard, chlorhexidine (CHX) has historically taken a key role in chemical biofilm control. It is a cationic bisbiguanide and has frequently been used in general medicine as a broad-spectrum antiseptic since 1953 [3]. It has proven to be an efficient agent against oral biofilms as well and displays antimicrobial activity against gram-positive and -negative bacteria, yeasts, and viruses, including human immunodeficiency virus (HIV) and hepatitis B virus [4]. The effect is dose-dependent. Whereas $\mathrm{CHX}$ is bacteriostatic at low concentrations, higher concentrations also exhibit a bactericidal effect $[5,6]$. $\mathrm{CHX}$ has been shown to penetrate biofilms as well, altering biofilm formation or having a direct bactericidal effect [7,8]. The mode of action is explained as follows: As the bacterial cell is negatively charged, the cationic $\mathrm{CHX}$-molecule binds to the cell surface. The integrity of the bacterial cell is thereby altered in such a way that $\mathrm{CHX}$ can penetrate the inner cell membrane leading to a higher permeability. This results in leakage phenomena of lowmolecular-weight components. At this point, the antimicrobial action is still at the bacteriostatic stage and can still be reversed if $\mathrm{CHX}$ is removed and the bacterial cell can recover. Stable or increasing $\mathrm{CHX}$ concentrations, however can lead to irreversible cell damage, i.e. cytoplasm coagulation and precipitation due to the formation of phosphate complexes such as adenosine triphosphate and nucleic acids [3,9].

Due to mostly negatively charged oral surfaces like teeth or the mucosa, $\mathrm{CHX}$ molecules display good adherence to these surfaces and thereby interfere with bacterial adhesion [5,10-13]. Further, $\mathrm{CHX}$ interacts with salivary glycoproteins. After rinsing with $\mathrm{CHX}$, the saliva has been shown to exhibit an antibacterial activity for approximately five hours [14,15]. In addition, it has been suggested that $\mathrm{CHX}$ interferes with glucan production [16]. $\mathrm{CHX}$ binding to oral soft tissues allows substantivity for up to 12 hours [3]. Based on this mode of action and these properties, $\mathrm{CHX}$ is frequently used as mouth-rinse. The pharmacokinetics are favorable, as it is easy to reach an effective dosage of the active agent. Noteworthy, a mouth-rinse can be used independently of the patient's ability to brush his teeth and is further well accepted by patients. This makes it an ideal preventive measure after surgical interventions, especially when 
mechanical cleaning, for instance, is not possible or in clinical situations, in which mechanical plaque and inflammation control may be difficult due to discomfort or postoperative pain. However, this chemical plaque control is conceived for use on a short-term basis [3].

The clinically applied $\mathrm{CHX}$ concentrations mostly vary between $0.1-0.2 \%$ and allow for reaching the ideal dosage of 18-20 mg per application. To reach a $20 \mathrm{mg}$ dose with a $0.2 \%$ concentration, $10 \mathrm{~mL}$ of solution must be applied for at least 30 seconds; with a $0.12 \%$ concentration, $15 \mathrm{~mL}$ of solution must be applied for 60 seconds $[3,17,18]$.

A beneficial clinical effect can already be observed with dosages of 5-6 mg, whereas dosages than $20 \mathrm{mg}$ have been shown not to necessarily increase the effect. No adverse microbiologic changes, such as the overgrowth of opportunistic strains, when observing long-term use, have been reported so far, irrespective of the concentration used [19-21]. However, side effects must be taken into consideration ${ }^{18}$. In this context, temporary taste alteration [22,23], staining of teeth, mucosa and/or tongue [24] and increase in calculus formation [25] have frequently been described. Staining, however, remains the most common adverse side effect. The degree of staining seems to correlate with the frequency of consumption of chromogenic products such as coffee, tea, wine, and tobacco as well as with the concentration of $\mathrm{CHX}[26,27]$. In recent years, research and development has focused on developing different methods to reduce staining while maintaining $\mathrm{CHX}$ efficacy. Recently mouth-rinses with lower concentrations and/or in combination with other ingredients such as herbal extracts or hyaluronic acid have been assessed in order to decrease such side effects [28-30]. A so-called anti-discoloration system (ADS) has also been implemented [31-34].

After periodontal and implant surgery, CHX mouth-rinses are most commonly prescribed. In 2017 a systematic review found it to be the most frequently used antiseptic agent after surgical intervention [35].

Despite the aforementioned disadvantages, chemical plaque control remains a must for most clinicians. An older study from Hemp et al. (1975), where gingival biopsies were taken at wound sites in dogs after plaque had been allowed to accumulate, showed a general increase in gingival inflammation [36].

Nevertheless, and surprisingly enough, only a few studies have evaluated the benefit of $\mathrm{CHX}$ rinsing after periodontal or implant surgery and to the best of our knowledge, no systematic evaluation has been performed so far. Furthermore, systematic studies have not yet screened for optimal concentrations or compositions, which should be used to achieve optimal clinical 
results with the least possible side effects. Therefore, this systematic review aimed for the first time to evaluate the benefit of $\mathrm{CHX}$ after periodontal or implant surgery compared to rinsing with a placebo and second to discern the influence of different concentrations and formulations in terms of efficacy, side effects and patient acceptance. We hypothesized, as shown for gingivitis prophylaxis and non-surgical periodontal therapy [37, 38-44], that rinsing with $\mathrm{CHX}$

1) Results in less plaque formation and bleeding as compared to placebo control

2) Novel formulations are able to reduce side effects while still being effective, i.e. are as effective in plaque and bleeding reduction as the respective control (standard $\mathrm{CHX}$-formulation).

\section{Materials and Methods:}

\section{Protocols}

A systematic literature search has been conducted and studies published from 1976 through June 2018 were included.

The review was conducted according to the Preferred Reporting Items for Systematic Reviews and Meta-Analyses (PRISMA) criteria. (Fig.1) The research question was assessed using the population, intervention, comparison and outcomes (PICO) method.

Two specific questions were addressed as follows according to the PICO principles:

1. In patients undergoing periodontal or implant surgery (Population), does Chlorhexidine rinsing as post-treatment protocol (Intervention) have a beneficial effect on clinical periodontal parameters and healing (Outcome) compared to rinsing with placebo-solution (Control)?

2. In patients undergoing periodontal or implant surgery (Population), does rinsing with reduced $\mathrm{CHX}$-concentration or substitution by other adjuncts, as post-treatment protocol (Intervention) have the same beneficial effect on clinical periodontal parameters and healing with less adverse effects (Outcome) compared to rinsing with placebo-solution (Control)?

\section{Search strategy:}

The following databases were included: PubMed, MEDLINE, Embase and Cochrane library and the following MeSH terms were searched: 
Population/Health condition: Periodontal OR Periodontitis OR Paradontitis OR Parodontitis OR peri-implant OR Periodontal Disease OR Periimplantitis

Therapy: Surgery OR GBR/ Guided Bone Regeneration OR GTR OR Guided Tissue Regeneration OR OFD OR Open Flap Debridement OR Widman Flap OR Modified Widman Flap OR Recession Coverage OR Root Coverage OR Implant Placement OR Implant Surgery OR Tunnel Technique OR Apical Positioned Flap OR Coronal Advanced Flap OR Split Flap OR Papilla Preservation Flap OR Distal Wedge OR Root Resection OR Tunnel Preparation OR Gingivectomy OR Root section

Mouth-rinse: Chlorhexidine OR Chlorhexidine Phosphanilate OR Chlorhexidine di-gluconate OR Chlorhexidine Gluconate OR Zinc-chlorhexidine OR CHX OR CHX Formulations

\section{Screening and selection:}

Two authors (A.S. and M.K.) independently searched and screened the publications by title and abstract. The inclusion and exclusion criteria for the studies were as follows:

Inclusion criteria were:

- Randomized Controlled Trials (RCTs) evaluating CHX-rinsing after periodontal or implant surgery

- Control group using a placebo, nothing or a different $\mathrm{CHX}$-formulation

- Evaluation of efficacy (plaque and bleeding) and side-effects (staining)

Exclusion criteria were:

- In-vitro-studies

- Animal studies

- Non-RCT study designs

Available titles and abstracts were collected and discussed before being finally included or excluded. Inter-examiner agreement of a Cohen's kappa $(K)$ of 0.6 was achieved after initial screening. Authors discussed discrepancies until reaching consent. If required, the senior author (PRS) was consulted.

The articles finally selected were analyzed as full texts (Fig. 1).

Studies were divided in two groups according to the type of question:

1) Results for plaque formation and bleeding, as compared to placebo control 
2) Novel formulations are able to reduce side effects while still being effective, i.e. are as affective in plaque and bleeding reduction as the respective control

Data (plaque accumulation, bleeding on probing (BOP) and tooth-staining) was extracted by both reviewers separately.

Assessing the data, it was noted that the various studies used different scales and indices. Therefore, the authors agreed that the data be converted into a common unit, using percentage measurements in order to compare and interpret the results more easily.

\section{Quality assessment}

Quality assessment of the RCT's using the Oxford quality scoring system by two authors (A.S. and M.K., Table 1) [45]. The Oxford scale assesses independently the methodological quality of a clinical trial judging the effectiveness of blinding described, the description of the randomization and drop-outs.

A score of between zero (very poor) and five (rigorous) scale is described.

Included studies received a 3- to 5-point score (max. 5 points) with a mean of 4.18. All eleven studies described randomized studies; three of which were not explicitly described as doubleblinded [29, 30, 47] and three investigations were split-mouth trials [46, 47, 48].

In five trials, sample size calculation was performed and a statistical power of $80-85 \%$ could be reached $[28,29,49,50,54]$.

A relatively low number of patients (9 to 53 patients) in some of the studies could be considered as a potential limitation of the results obtained.

Noteworthy was that seven of the eleven publications explicitly reported that they had no conflict of interests [28, 29, 30, 49, 50, 54, 61], whereas four studies did not mention this aspect [1, 46, $47,48]$.

\section{Outcome measures:}

The main focus of this study was to filter out the benefits of a prescripted Chlorhexdine rinsing solution after periodontal or implant surgery on evaluation parameters such as plaque-index (PI) and bleeding-on-probing (BOP). In addition, changes in staining were tested. These primary outcomes were illustrated in different tables. Secondary parameter outcomes such as periodontal probing depth (PPD) and patient acceptance were described narratively since the data was very heterogenous. 


\section{$\underline{\text { Results }}$}

In this review, we evaluated the benefits of chlorhexidine rinsing after periodontal or implant surgery in terms of plaque and inflammation reduction potential as compared to a placebo (Table 2). Further, we screened whether concentration changes or additives in $\mathrm{CHX}$ solutions were able to reduce side effects. The results are presented separately in the following sections.

\section{CHX vs. Placebo}

\section{Plaque}

A summary of the plaque reducing potential of chlorhexidine after surgery as compared to placebo is depicted in Table 3 . All four studies $[1,46,47,48]$ assess the plaque reduction after rinsing with $\mathrm{CHX}$ and employ a placebo mouth rinse for comparison. Although $\mathrm{CHX}$ rinses are of different concentrations and vary between $0.12 \%[46,47]$ and $0.2 \%[1,48]$, all studies reported significantly less plaque accumulation with use of the $\mathrm{CHX}$ rinses as compared to the placebo groups. The reduction potential after 1 week ranged from $29 \%$ [1] to $86 \%$ [47]. After 2 weeks, it ranged between $50.9 \%$ [1] and $82 \%$ [48].

\section{Gingival parameters}

In terms of bleeding on probing (BOP) reduction, which was assessed in all four studies, the results ranged from $0 \%$ to $73 \%$ after 1 week (Table 4 ) $[46,48]$. Sanz et al. (1989) found that chlorhexidine led to a $16.8 \%$ and $10.3 \%$ reduction of gingivitis severity (average extent of the disease) after 4 and 6 weeks as compared to the control, respectively. With regard to gingival bleeding, $\mathrm{CHX}$ reduced the index score by about $40 \%$ after 4 and 6 weeks.

For wound healing and epithelialization, no statistically significant differences could be found, although the CHX group showed consistently better epithelialization [1].

Regarding sulcus bleeding index, Newman \& Addy and Vaughan \& Garnick also found a high statistical difference when $\mathrm{CHX}$ was used after surgery, compared to the placebo rinse, however this difference was no longer present after 1 and 3 months, when routine oral hygiene was reinstructed $[46,47]$.

With regard to crevicular fluid flow rate during chlorhexidine-rinsing, no significant differences could be observed [47]. It was also found that $\mathrm{CHX}$ had no significant effect on the gingival inflammation parameters under periodontal dressings [48].

\section{Probing Pocket depth}

Two studies assessed the question, whether chlorhexidine rinsing could improve the clinical outcome after surgery as measured by periodontal pocket depth reduction resulting in a longterm effect. Irrespective of whether a chlorhexidine rinse was used or not they found that there was no additional benefit $[1,46]$. Therefore, no beneficial long-term effect could be seen from postoperative administrated $\mathrm{CHX}$ over placebo rinsing. 


\section{Patient acceptance}

Overall patient compliance with $\mathrm{CHX}$ usage was not necessarily hindered by its side effects. $\mathrm{CHX}$ is known for several side effects, especially when used for longer periods.

Three out of four studies reported on these parameters. On the development of post-surgical pain, patients reported no advantage when using $\mathrm{CHX}$. Also, there was no difference in the amount of pain medication used $[1,47]$.

As expected, significantly more staining $(p=0.017)$ after the use of chlorhexidine was described by one study [1], which supports prior findings [24].

In a questionnaire, $67 \%$ of the patients liked and $24 \%$ disliked the taste of $\mathrm{CHX}$ [1].

The amount of self-perceived swelling was found to be greater in the $\mathrm{CHX}$ group $(p=0.016)$ [47].

\section{Novel chlorhexidine formulations}

CHX vs. alcohol-free $\mathrm{CHX}$

An overview of included publications assessing different $\mathrm{CHX}$-formulations is provided in table 5 . The comparison of alcohol-free with alcohol-based solutions was described in two studies [49,61]. Alcohol-free $\mathrm{CHX}$ solutions have been introduced in an attempt to lower side effects. Alcohol is basically used to dissolve other compounds in the solution, and an antiseptic effect has also been discussed.

Olsson et al. 2012 carried out an RCT assessing the difference between alcohol-based CHX rinse and non-alcohol based $\mathrm{CHX}$ rinse on 20 patients after periodontal surgery. They did not find any significant differences in plaque-inhibition or amount of staining between the two solutions. This result agrees with findings of other non-surgical studies [49].

Both solutions were accepted equally well by the patients. Van Strydonck et al. reported, however, that patients preferred the taste of the alcohol-free $\mathrm{CHX}$ [50].

In 2018, Gkatzonis et al. conducted a study with 42 patients assessing the efficacy of both alcohol-based and alcohol-free solutions, as well as a third non-chlorhexidine solution (C31G). The trial resulted in significant superior plaque control of alcohol-based $\mathrm{CHX}$ over alcohol-free $\mathrm{CHX}$ and the third solution $(\mathrm{p}<0.001)$. Despite showing no statistically significant differences in terms of post-surgical wound healing between the three solutions, it hints that the presence of alcohol may increase the efficacy of $\mathrm{CHX}$ in the early wound healing response $(\mathrm{EHI}=$ early wound healing index) [61]. 


\section{CHX with ADS systems}

Due to its main side effect of staining, and with it the possibility of reduced compliance, $\mathrm{CHX}$ mouthrinses with additional anti-discoloration-system (ADS) have been introduced. The combination of $\mathrm{CHX}$ with metabisulphite, peroxiborate, polyvinyl porrylidone and ascorbic acid has been described to interfere with pigmentation processes. While some studies have shown the ADS does not interfere with the antiplaque capacity of $\mathrm{CHX}$ [33] others studies have shown the opposite, that the addition of these substances reducing the efficacy of CHX [51]. The staining incidence has been shown in some studies to be significantly lower than without these additives [52,53], while other studies did not show any statistical differences $[33,50]$.

Two RCTs specifically dealing with the use of $\mathrm{CHX}$ with anti-discoloration-system (ADS) after periodontal surgery were identified. In 2008, Cortellini et al. compared a $0.2 \% \mathrm{CHX}$ rinse with a $0.2 \% \mathrm{CHX}$ rinse with ADS. Bevilacqua et al. in 2016 additionally included $0.12 \% \mathrm{CHX}$ in his comparative clinical trial. No differences could be found regarding efficacy of plaque inhibition and improvement of post-surgical healing in either study. In terms of staining, according to Cortellini et al. $\mathrm{CHX}$ with ADS showed clearly less pigmentations than the control $\mathrm{CHX}[50]$. The $\mathrm{CHX}$-solution with ADS was found to be better tolerated than the $\mathrm{CHX}$ without additives in both studies. Further it caused less alteration in food taste and salt perception than the control solution. Finally, the test CHX with ADS showed less irritation to the oral tissues. The adjunct of ADS could be of value after surgery where patient compliance is very important in terms of reducing microbial colonization in surgical sites. Bevilacqua et al. could not find any significant difference between the $0.2 \% \mathrm{CHX}-, 0.2 \%$ with $\mathrm{ADS}$ - and $0.12 \%$ - groups tested regarding efficacy or staining [54].

\section{Other $\mathrm{CHX}$ formulations}

Genovesi et al. 2015 conducted an RCT with 40 patients after implant surgery comparing a 0.12 $\% \mathrm{CHX}$ mouthwash to a $0.12 \% \mathrm{CHX}$ plus hyaluronic acid mouthwash. The authors stated that hyaluronic acid in earlier studies seemed to be involved in the reduction of inflammation and in the promotion of re-epithelialization. The anti-oedematigenous effect of hyaluronic acid was confirmed in this study. Only $20 \%$ of patients treated with a hyaluronic acid additive showed edema, whereas $78 \%$ of the patient treated with only $\mathrm{CHX}$ showed edema at the surgical site after 2 days ( $p=0.0009$ ). In regards to anti-plaque and anti-gingivitis efficiency, no significant differences were noted by the authors. Further, both solutions showed no difference in the amount of staining produced [28].

Essential oils are known in medicine for their antimicrobial and anti-inflammatory properties. Gursoy et al. evaluated the effect of essential oils on periodontitis associated bacteria, 
suggesting they inhibit growth of periodontitis-associated bacteria [55]. It was also demonstrated that plant extracts could inhibit the growth of oral biofilm similar to $\mathrm{CHX}$.

A research group in the periodontology department at the University of Bern conducted two trials comparing $0.1 \% \mathrm{CHX}$ and $0.05 \% \mathrm{CHX}$ with herbal extract added after periodontal and implant surgeries in 2010 and 2015, the results of which support the above-mentioned theories [29,30]. No statistical differences were found for early wound healing, the reduction of probing pocket depth and reduction of the subgingival bacteria between the two solutions. While in the herbal extract group in both trials significantly lower tooth staining was observed, it could not be completely avoided. Even the ability to actively facilitate stain removal by the herbal extracts was discussed. Further, patients in the test group reported less loss of taste. The authors concluded that the lower concentration of $\mathrm{CHX}$ enhanced with herbal extracts may bring a benefit comparable to regular $\mathrm{CHX}$ solutions for long-term application.

\section{Discussion}

Chlorhexidine remains a widely and routinely prescribed rinsing solution after periodontal or implant surgery despite known side effects and interactions with healing [3]. This systematic review assessed the benefits of $\mathrm{CHX}$ after periodontal or implant surgery for the major clinical surrogate parameters of plaque, gingival inflammation and bleeding as compared to rinsing with a placebo. Further, the influence of different concentrations and formulations in terms of efficacy, side effects and patient acceptance were evaluated as well.

Eleven studies could be finally included in this review. Four studies compared the effect of $\mathrm{CHX}$ to a placebo solution whereas seven evaluated alternative $\mathrm{CHX}$ formulation in terms of clinical effectiveness and side effects. Despite the fact that $\mathrm{CHX}$ after surgery is part of the routine protocol employed in most practices, to the best of our knowledge, this review represents the first attempt to systematically assess the benefits of $\mathrm{CHX}$-rinsing after periodontal or implant surgery. No systematic review has yet evaluated alternative $\mathrm{CHX}$ formulations in these indications as well. Systematic reviews on $\mathrm{CHX}$ in periodontology or implant dentistry have mainly focused on the benefits and risks after scaling and root planning to date $[41,43]$. Furthermore, only eleven clinical trials qualified for the inclusion in this review and evaluated post-surgical rinsing with $\mathrm{CHX}$ after periodontal or implant surgery and comparing this regimen with a placebo control. 
It is well accepted, however, that rinsing with $\mathrm{CHX}$ after surgery represents a valuable adjunct in periodontal therapy in order to help patients reach a plaque-free or -reduced oral environment for optimized post-surgical healing, when mechanical cleaning at affected sites is not possible. Gartenmann et al. described Chlorhexidine as the most frequently used antiseptic agent used for 2 weeks following periodontal intervention [35].

Therefore, the results of this review may not be completely surprising. A meta-analysis of trials assessing $\mathrm{CHX}$ use after conventional SRP showed a slight but significant improvement of clinical attachment level and probing depth for patients rinsing with $\mathrm{CHX}$ over patients using a placebo solution [41]. These results are only partly reflected with the findings after periodontal surgery mentioned in this evaluation, where no significant improvement in pocket probing depth were found $[1,46]$. Beiswanger et al. published a study showing a mean plaque-reduction of $54 \%$ two and four weeks after conventional SRP and CHX mouth rinsing [56]. These results are comparable to the findings described after surgery. In 2017, James et al. published a systematic review that included 51 trials, about the benefit of $\mathrm{CHX}$ on gingival health. ${ }^{57}$ An evaluation of the plaque indices in 12 different trials on 950 patients showed a large effect for $\mathrm{CHX}$ as compared to a placebo or no control rinse after 4 and 6 weeks. In terms of BOP/bleeding scores after initial SRP, a reduction of $48 \%$ in favor of $\mathrm{CHX}$ versus a placebo after two and four weeks was described previously [56]. In the review by James at al. the overall effect of CHX was judged as moderate (SMD -0.56) [57]. Results after surgery seem to be very similar, as found in the present review.

In the second part of this review, attention was paid to studies, which aimed to maintain or improve the $\mathrm{CHX}$ efficacy, while lowering side effects, by modifying the formulation. It was not surprising that the main side effects of tooth-staining and taste alterations were mentioned in most studies evaluated. The addition of a so-called anti-discoloration system (ADS) lowering the $\mathrm{CHX}$ concentration or supplementation with herbal extracts were the main measures to counteract possible side-effects. In general, results for these additives were contradictory. In addition, a comparable antibacterial effect was also not consistently achieved.

Regarding differences between alcohol- or water-based $\mathrm{CHX}$ formulations, the findings are inconsistant. While Olsson et al. state there are no differences regarding plaque control or wound healing [49], Gkatzonis et al. report a significant better plaque control by alcohol-based solutions [61]. Alcohol was not shown to alleviate the side-effects of $\mathrm{CHX}$ in the studies assessed.

With respect to the $\mathrm{CHX}$ concentration, lower concentrations $(0.12 \%)$ displayed a similar clinical effectivity as the $0.2 \%$ concentrated solution. However, a lower concentration seemed to reduce 
side effects $[29,30]$. Lowering $\mathrm{CHX}$ concentration, in combination with herbal extract additives, might be a good approach as shown in the few studies. In some trials, herbal extracts have been compared to $\mathrm{CHX}$ solutions, whereby slight clinical benefits were found [58-60]. No in vivo trials could be found evaluating a mixed herbal/CHX solution, however.

All RCTs reported clinical benefits when using $\mathrm{CHX}$ to prevent biofilm accumulation on nonshedding tooth surfaces after surgery, which supports the finding of studies that evaluated $\mathrm{CHX}$ rinsing after initial SRP-treatment [47].

Additional trials are therefore still needed to definitively evaluate the benefits of rinsing with $\mathrm{CHX}$ after periodontal surgery or implant placement, as the number of clinical trials available are relatively small. This represents an essential limitation to our systematic review, despite the fact this topic is not at all new. Further, comparison of the results is difficult due to inconsistent outcome parameters and measurement techniques. Notably, different scales and indices were used in the various studies, despite the fact that most assessed comparable clinical situations and outcome parameters, i.e. plaque accumulation, gingival inflammation and wound healing. In addition, the observation periods varied widely between studies. A standardized comparison and meta-analysis was therefore not possible. Therefore, in order to identify an optimal spectrum of efficacy, with minimal side effects, additional clinical trials are still warranted.

\section{Conclusion}

Within the limitations of this systematic review, it can be concluded that $\mathrm{CHX}$ rinsing helps to reduce plaque accumulation and gingival inflammation after periodontal and implant surgery. On the short term, $\mathrm{CHX}$ is a valuable chemo-preventive tool, especially during the time period in which self-performed oral hygiene is compromised. However, as data from two studies (49 patients) has shown, current rinsing concepts have no positive effect on long term PPD reduction when compared to a placebo solution. Further, data from seven studies (247 patients) provided comparable clinical results when patients rinsed with reduced $\mathrm{CHX}$ concentrations (e.g. $0.12 \%$ vs $0.2 \%$ ) in order to reduce side effects. 


\section{References:}

1. Sanz, M. et al. Clinical enhancement of post-periodontal surgical therapy by a $0.12 \%$ chlorhexidine gluconate mouthrinse. Journal of periodontology 60, 570-576 (1989).

2. Newman, M. G., Sanz, M., Nachnani, S., Saltini, C. \& Anderson, L. Effect of $0.12 \%$ chlorhexidine on bacterial recolonization following periodontal surgery. Journal of periodontology 60, 577-581 (1989).

3. Jan, L. Clinical Periodontology and Implant Dentistry, 2 Volume Set. (2015).

4. Wade, W. G. \& Addy, M. In vitro activity of a chlorhexidine-containing mouthwash against subgingival bacteria. J Periodontol 60, 521-525 (1989).

5. Fine, D. H. Mouthrinses as adjuncts for plaque and gingivitis management. A status report for the American Journal of Dentistry. Am J Dent 1, 259-263 (1988).

6. Hugo, W. B. \& Longworth, A. R. The effect of chlorhexidine on the electrophoretic mobility, cytoplasmic constituents, dehydrogenase activity and cell walls of Escherichia coli and Staphylococcus aureus. J Pharm Pharmacol 18, 569-578 (1966).

7. Arweiler, N. B., Netuschil, L. \& Reich, E. Alcohol-free mouthrinse solutions to reduce supragingival plaque regrowth and vitality. A controlled clinical study. J Clin Periodontol 28, 168-174 (2001).

8. Shapiro, S., Giertsen, E. \& Guggenheim, B. An in vitro oral biofilm model for comparing the efficacy of antimicrobial mouthrinses. Caries Res 36, 93-100 (2002).

9. Jones, C. G. Chlorhexidine: is it still the gold standard. Periodontol 2000 15, 55-62 (1997).

10. Rölla, G. \& Melsen, B. On the mechanism of the plaque inhibition by chlorhexidine. J Dent Res 54 Spec No B, B57-62 (1975).

11. Wolff, L. F. Chemotherapeutic agents in the prevention and treatment of periodontal disease. Northwest Dent 64, 15-24 (1985).

12. Jenkins, S., Addy, M. \& Wade, W. The mechanism of action of chlorhexidine. A study of plaque growth on enamel inserts in vivo. J Clin Periodontol 15, 415-424 (1988).

13. Jenkins, S., Addy, M. \& Newcombe, R. Studies on the effect of toothpaste rinses on plaque regrowth. (II). Triclosan with and without zinc citrate formulations. J Clin Periodontol 16, 385-387 (1989).

14. Roberts, W. R. \& Addy, M. Comparison of the bisbiguanide antiseptics alexidine and chlorhexidine. I. Effect on plaque accumulation and salivary bacteria. J Clin Periodontol 8, 213-219 (1981).

15. Rölla, G., Loe, H. \& Schiott, C. R. Affinity of chlorhexidine gluconate to hydroxylapatite and to salivary mucins. Caries Res 5, 23 (1971). 
16. Vacca-Smith, A. M., Venkitaraman, A. R., Quivey, R. G. \& Bowen, W. H. Interactions of streptococcal glucosyltransferases with alpha-amylase and starch on the surface of salivacoated hydroxyapatite. Arch Oral Biol 41, 291-298 (1996).

17. Löe, H., Schiött, C. R., Karring, G. \& Karring, T. Two years oral use of chlorhexidine in man. I. General design and clinical effects. J Periodontal Res 11, 135-144 (1976).

18. Flemmig, T. F. et al. Supragingival irrigation with $0.06 \%$ chlorhexidine in naturally occurring gingivitis. I. 6 month clinical observations. J Periodontol 61, 112-117 (1990).

19. Schiott, C. R. Effect of chlorhexidine on the microflora of the oral cavity. J Periodontal Res Suppl 12, 7-10 (1973).

20. Schiott, C. R., Briner, W. W. \& Löe, H. Two year oral use of chlorhexidine in man. II. The effect on the salivary bacterial flora. J Periodontal Res 11, 145-152 (1976).

21. Schiott, C. R., Briner, W. W., Kirkland, J. J. \& Löe, H. Two years oral use of chlorhexidine in man. III. Changes in sensitivity of the salivary flora. J Periodontal Res 11, 153-157 (1976).

22. Breslin, P. A. \& Tharp, C. D. Reduction of saltiness and bitterness after a chlorhexidine rinse. Chem Senses 26, 105-116 (2001).

23. Marinone, M. G. \& Savoldi, E. Chlorhexidine and taste. Influence of mouthwashes concentration and of rinsing time. Minerva Stomatol 49, 221-226 (2000).

24. Flötra, L., Gjermo, P., Rölla, G. \& Waerhaug, J. Side effects of chlorhexidine mouth washes. Scand J Dent Res 79, 119-125 (1971).

25. Yates, R. et al. A 6-month home usage trial of a $1 \%$ chlorhexidine toothpaste (1). Effects on plaque, gingivitis, calculus and toothstaining. J Clin Periodontol 20, 130-138 (1993).

26. Addy, M., Wade, W. G., Jenkins, S. \& Goodfield, S. Comparison of two commercially available chlorhexidine mouthrinses: I. Staining and antimicrobial effects in vitro. Clin Prev Dent 11, 10-14 (1989).

27. Claydon, N. et al. The effect of polyvinyl pyrrolidone on the clinical activity of $0.09 \%$ and 0.2\% chlorhexidine mouthrinses. J Clin Periodontol 28, 1037-1044 (2001).

28. Genovesi, A., Barone, A., Toti, P. \& Covani, U. The efficacy of $0.12 \%$ chlorhexidine versus $0.12 \%$ chlorhexidine plus hyaluronic acid mouthwash on healing of submerged single implant insertion areas: a short-term randomized controlled clinical trial. International journal of dental hygiene 15, 65-72 (2017).

29. Duss, C., Lang, N. P., Cosyn, J. \& Persson, G. R. A randomized, controlled clinical trial on the clinical, microbiological, and staining effects of a novel $0.05 \%$ chlorhexidine/herbal extract and a $0.1 \%$ chlorhexidine mouthrinse adjunct to periodontal surgery. Journal of clinical periodontology 37, 988-997 (2010). 
30. Laugisch, O. et al. Effects of two different post-surgical protocols including either $0.05 \%$ chlorhexidine herbal extract or $0.1 \%$ chlorhexidine on post-surgical plaque control, early wound healing and patient acceptance following standard periodontal surgery and implant placement. Clinical oral investigations 20, 2175-2183 (2016).

31. Gründemann, L. J., Timmerman, M. F., ljzerman, Y., van der Weijden, G. A. \& van der Weijden, G. A. Stain, plaque and gingivitis reduction by combining chlorhexidine and peroxyborate. J Clin Periodontol 27, 9-15 (2000).

32. Claydon, N., Addy, M., Jackson, R., Smith, S. \& Newcombe, R. G. Studies on the effect of polyvinyl pyrrolidone on the activity of chlorhexidine mouthrinses: plaque and stain. $J$ Clin Periodontol 28, 558-564 (2001).

33. Bernardi, F., Pincelli, M. R., Carloni, S., Gatto, M. R. \& Montebugnoli, L. Chlorhexidine with an Anti Discoloration System. A comparative study. Int J Dent Hyg 2, 122-126 (2004).

34. Addy, M., Sharif, N. \& Moran, J. A non-staining chlorhexidine mouthwash? Probably not: a study in vitro. Int J Dent Hyg 3, 59-63 (2005).

35. Gartenmann, S. J. et al. Influence of different post-interventional maintenance concepts on periodontal outcomes: an evaluation of three systematic reviews. BMC Oral Health 17, 19 (2016).

36. Hamp, S. E., Rosling, B. \& Lindhe, J. Effect of chlorhexidine on gingival wound healing in the dog. A histometric study. J Clin Periodontol 2, 143-152 (1975).

37. Axelsson, P. \& Lindhe, J. Efficacy of mouthrinses in inhibiting dental plaque and gingivitis in man. J Clin Periodontol 14, 205-212 (1987).

38. Quirynen, M. et al. Full- vs. partial-mouth disinfection in the treatment of periodontal infections: short-term clinical and microbiological observations. J Dent Res 74, 1459-1467 (1995).

39. Christie, P., Claffey, N. \& Renvert, S. The use of $0.2 \%$ chlorhexidine in the absence of a structured mechanical regimen of oral hygiene following the non-surgical treatment of periodontitis. J Clin Periodontol 25, 15-23 (1998).

40. Faveri, M. et al. Scaling and root planing and chlorhexidine mouthrinses in the treatment of chronic periodontitis: a randomized, placebo-controlled clinical trial. J Clin Periodontol 33, 819-828 (2006).

41. da Costa, L. F. N. P., Amaral, C. D. S. F., Barbirato, D. D. S., Leão, A. T. T. \& Fogacci, M. F. Chlorhexidine mouthwash as an adjunct to mechanical therapy in chronic periodontitis: A meta-analysis. J Am Dent Assoc 148, 308-318 (2017).

42. Stratul, S. I. et al. Prospective clinical study evaluating the long-time adjunctive use of chlorhexidine after one-stage full-mouth SRP. Int J Dent Hyg 8, 35-40 (2010). 
43. Figuero, E. et al. Mechanical and chemical plaque control in the simultaneous management of gingivitis and caries: a systematic review. J Clin Periodontol 44 Suppl 18, S116-S134 (2017).

44. Tenenbaum, H. et al. An 8-week, randomized, controlled, clinical study of the use of a $0.1 \%$ chlorhexidine mouthwash by chronic periodontitis patients. J Investig Clin Dent 2, 2937 (2011).

45. Jadad, A. R. et al. Assessing the quality of reports of randomized clinical trials: is blinding necessary. Control Clin Trials 17, 1-12 (1996).

46. Newman, P. S. \& Addy, M. Comparison of hypertonic saline and chlorhexidine mouthrinses after the inverse bevel flap procedure. Journal of periodontology 53, 315-318 (1982).

47. Vaughan, M. E. \& Garnick, J. J. The effect of a $0.125 \%$ chlorhexidine rinse on inflammation after periodontal surgery. Journal of periodontology 60, 704-708 (1989).

48. Langebaek, J. \& Bay, L. The effect of chlorhexidine mouthrinse on healing after gingivectomy. Scandinavian journal of dental research 84, 224-228 (1976).

49. Olsson, H., Asklow, B., Johansson, E. \& Slotte, C. Rinsing with alcohol-free or alcoholbased chlorhexidine solutions after periodontal surgery. A double-blind, randomized, crossover, pilot study. Swedish dental journal 36, 91-99 (2012).

50. Cortellini, P. Labriola, A. Zambelli, R. Pini Prato, G. Nieri, M. Tonetti, MS. Chlorhexidine with an anti discoloration system after periodontal flap surgery: a cross-over, randomized, triple-blind clinicl trial. J Clin Periodontol 35: 614-620 (2008).

51. Arweiler, N. B., Boehnke, N., Sculean, A., Hellwig, E. \& Auschill, T. M. Differences in efficacy of two commercial $0.2 \%$ chlorhexidine mouthrinse solutions: a 4-day plaque regrowth study. J Clin Periodontol 33, 334-339 (2006).

52. Addy, M., Sharif, N. \& Moran, J. A non-staining chlorhexidine mouthwash? Probably not: a study in vitro. Int J Dent Hyg 3, 59-63 (2005).

53. Li, W., Wang, R. E., Finger, M. \& Lang, N. P. Evaluation of the antigingivitis effect of a chlorhexidine mouthwash with or without an antidiscoloration system compared to placebo during experimental gingivitis. J Investig Clin Dent 5, 15-22 (2014).

54. Bevilacqua, L., Liani, G., Castronovo, G. \& Costantinides, F. Clinical and spectrophotometric evaluation after chlorhexidine use in periodontal flap surgery: $A$ prospective randomized clinical trial. Am J Dent 29, 75-80 (2016).

55. Gursoy, U. K. et al. Anti-biofilm properties of Satureja hortensis L. essential oil against periodontal pathogens. Anaerobe 15, 164-167 (2009).

56. Beiswanger, B. B. et al. Clinical effects of a $0.12 \%$ chlorhexidine rinse as an adjunct to scaling and root planing. J Clin Dent 3, 33-38 (1992). 
57. James, P. et al. Chlorhexidine mouthrinse as an adjunctive treatment for gingival health. Cochrane Database Syst Rev 3, CD008676 (2017).

58. Pathan, M. M., Bhat, K. G. \& Joshi, V. M. Comparative evaluation of the efficacy of a herbal mouthwash and chlorhexidine mouthwash on select periodontal pathogens: $J$ Indian Soc Periodontol 21, 270-275 (2017).

59. Gupta, D. et al. Are herbal mouthwash efficacious over chlorhexidine on the dental plaque. Pharmacognosy Res 7, 277-281 (2015).

60. Manipal, S., Hussain, S., Wadgave, U., Duraiswamy, P. \& Ravi, K. The Mouthwash War Chlorhexidine vs. Herbal Mouth Rinses: A Meta-Analysis. J Clin Diagn Res 10, ZC81-3 (2016).

61. Gkatzonis, A.M., Vassilopoulos, S., Karoussis, I.K., Kaminari, A., Madianos, P.N., Vrostos, I.A. A randomized controlled clinical trial on the effectiveness of three different mouthrinses (chlorhexidine with or without alcohol and C31G), adjunct to periodontal surgery, in early wound healing. Clin Oral Investig 2018 Feb 2. 
Tables

Table 1

Quality assessment via Oxford quality scoring system [45].

\begin{tabular}{|c|c|c|c|c|c|c|c|c|c|c|c|c|}
\hline & $\begin{array}{l}\mathscr{D} \\
\stackrel{3}{N} \\
\mathbb{N} \\
\mathbb{D} \\
\cong \\
\overrightarrow{0} \\
\stackrel{0}{0} \\
\Xi \\
\Xi\end{array}$ & 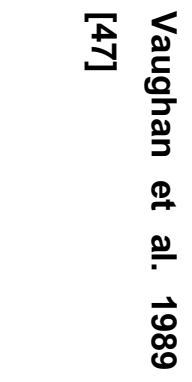 & 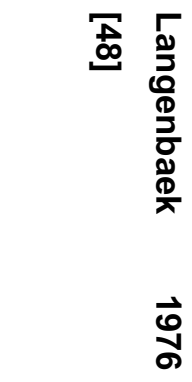 & 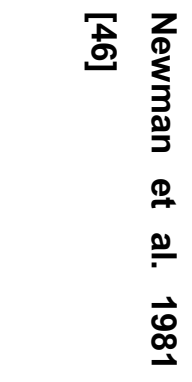 & 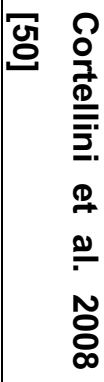 & 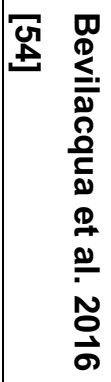 & 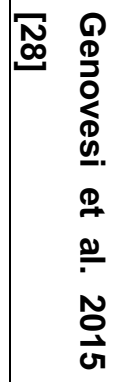 & 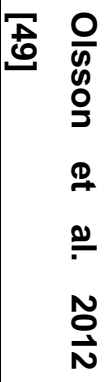 & 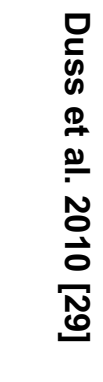 & 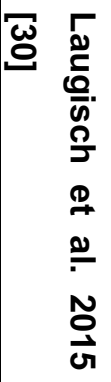 & 몰 & 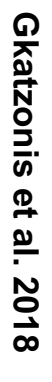 \\
\hline $\begin{array}{l}\text { Described as } \\
\text { randomized * }\end{array}$ & 1 & $\begin{array}{l}\text { Split- } \\
\text { mouth/1 }\end{array}$ & $\begin{array}{l}\text { Split- } \\
\text { mouth/1 }\end{array}$ & $\begin{array}{l}\text { Split- } \\
\text { mouth/1 }\end{array}$ & 1 & 1 & 1 & 1 & 1 & 1 & 1 & \\
\hline $\begin{array}{l}\text { Described as } \\
\text { double-blind * }\end{array}$ & 1 & 0 & 1 & 1 & 1 & 1 & 1 & 1 & 0 & 0 & 1 & \\
\hline $\begin{array}{l}\text { Randomization } \\
\text { method } \\
\text { described and } \\
\text { appropriate ** }\end{array}$ & 1 & $\begin{array}{l}\text { Split- } \\
\text { mouth/1 }\end{array}$ & $\begin{array}{l}\text { Split- } \\
\text { mouth/0 }\end{array}$ & $\begin{array}{l}\text { Split- } \\
\text { mouth/1 }\end{array}$ & 1 & 1 & 1 & 1 & 1 & 1 & 1 & \\
\hline $\begin{array}{l}\text { Double-blinding } \\
\text { method } \\
\text { described and } \\
\text { appropriate ** }\end{array}$ & 1 & 0 & 0 & 1 & 1 & 0 & 1 & 1 & 0 & 0 & 1 & \\
\hline $\begin{array}{l}\text { Drop-outs justified } \\
\text { * }\end{array}$ & 1 & 1 & 1 & 1 & 1 & 1 & 1 & 1 & 1 & 1 & 1 & \\
\hline SCORE & 5 & 3 & 3 & 5 & 5 & 4 & 5 & 5 & 3 & 3 & 5 & \\
\hline
\end{tabular}

* A study receives a sore of 1 for "yes" and 0 for "no"

${ }^{* *}$ A study receives a sore of 0 if no description is given, 1 if the method is described and appropriate, -1 if the method is described is inappropriate 
Table 2. Overview of the included publications comparing $\mathrm{CHX}$ to placebo.

\begin{tabular}{|c|c|c|c|c|c|c|c|}
\hline Author & $\begin{array}{l}\text { Rinsing } \\
\text { Agent }\end{array}$ & Concentration & $\begin{array}{l}\text { Intervention } \\
\text { \& Duration }\end{array}$ & $\begin{array}{l}\text { Sample } \\
\text { Size }\end{array}$ & $\begin{array}{l}\text { Follow- } \\
\text { up }\end{array}$ & Evaluation & $\begin{array}{l}\text { Study } \\
\text { Desig } \\
\mathrm{n}\end{array}$ \\
\hline $\begin{array}{l}\text { Sanz et al. } \\
1989 \text { [1] }\end{array}$ & $\begin{array}{l}\text { CHX vs. } \\
\text { Placebo }\end{array}$ & $0.12 \%$ & $\begin{array}{l}\text { Osseous } \\
\text { periodontal } \\
\text { surgery } \\
2 \times / d 30 \text { sec. } \\
\text { for } 6 \text { weeks }\end{array}$ & 40 & $\begin{array}{l}1,2,4,6 \\
\text { weeks }\end{array}$ & $\begin{array}{ll}\text { - } & \text { Plaque-Index } \\
\text { - } & \text { BOP } \\
\text { - } & \text { PPD } \\
\text { - } & \text { Epithelialization } \\
\text { - } & \text { Patients } \\
& \text { acceptance }\end{array}$ & RCT \\
\hline $\begin{array}{l}\text { Vaughan et } \\
\text { al. } 1989 \text { [47] }\end{array}$ & $\begin{array}{l}\text { CHX vs. } \\
\text { Placebo }\end{array}$ & $0.12 \%$ & $\begin{array}{l}\text { Open flap } \\
\text { debridement } \\
2 x / d \text { for } \\
2 \text { weeks }\end{array}$ & 9 & $\begin{array}{l}1,2 \\
\text { weeks }\end{array}$ & $\begin{array}{ll}\text { - } & \text { Plaque-Index } \\
\text { - } & \text { BOP } \\
\text { - } & \text { Crevicular fluid } \\
& \text { flow } \\
\text { - } & \text { Pain/swelling }\end{array}$ & $\begin{array}{l}\text { RCT } \\
\text { Cross- } \\
\text { over }\end{array}$ \\
\hline $\begin{array}{l}\text { Langenbaek } \\
1976 \text { [48] }\end{array}$ & $\begin{array}{l}\text { CHX vs. } \\
\text { Placebo }\end{array}$ & $0.2 \%$ & $\begin{array}{l}\text { Gingivectomy } \\
2 x / d \text { for } \\
3 \text { weeks }\end{array}$ & 24 & $\begin{array}{l}1,2,3 \\
\text { weeks }\end{array}$ & $\begin{array}{ll}\text { - } & \text { Plaque-Index } \\
\text { - } & \text { BOP }\end{array}$ & RCT \\
\hline $\begin{array}{l}\text { Newman et } \\
\text { al. } 1981 \text { [46] }\end{array}$ & $\begin{array}{l}\text { CHX vs. } \\
\text { Placebo } \\
(\mathrm{NaCl})\end{array}$ & $0,2 \%$ & $\begin{array}{l}\text { Inverse bevel } \\
\text { flap } \\
3 x / d \text { for } \\
1 \text { week }\end{array}$ & 9 & $\begin{array}{l}1 \text { week, } \\
1 \text { and } 3 \\
\text { months }\end{array}$ & $\begin{array}{ll}\text { - } & \text { Plaque-Index } \\
\text { - } & \text { BOP } \\
\text { - } & \text { PPD } \\
\text { - } & \text { Patients } \\
& \text { acceptance }\end{array}$ & $\begin{array}{l}\text { RCT } \\
\text { Cross- } \\
\text { over }\end{array}$ \\
\hline
\end{tabular}


Table 3. Reduction of plaque accumulation; $\mathrm{CHX}$ vs. Placebo.

\begin{tabular}{|c|c|c|c|c|c|}
\hline Author & $\begin{array}{l}\text { Rinsing } \\
\text { Agent }\end{array}$ & Concentration & Follow-up & $\begin{array}{l}\text { Mean Plaque-Index- } \\
\text { reduction of } \mathrm{CHX} \text { vs. } \\
\text { Placebo }\end{array}$ & $\begin{array}{l}\text { Significant } \\
\text { reduction } \\
\text { (overall) }\end{array}$ \\
\hline $\begin{array}{l}\text { Sanz et al. } \\
1989 \text { [1] }\end{array}$ & $\begin{array}{l}\text { CHX vs. } \\
\text { Placebo }\end{array}$ & $0,12 \%$ & $\begin{array}{l}1 \text { week } \\
2 \text { weeks } \\
4 \text { weeks } \\
6 \text { weeks }\end{array}$ & $\begin{array}{l}\text { - } 29 \% \\
\text { - } 50.9 \% \\
\text { - } 52.3 \% \\
\text { - } 54.4 \%\end{array}$ & yes \\
\hline $\begin{array}{l}\text { Vaughan et } \\
\text { al. } 1989 \text { [47] }\end{array}$ & $\begin{array}{l}\text { CHX vs. } \\
\text { Placebo }\end{array}$ & $0,12 \%$ & $\begin{array}{l}1 \text { week } \\
2 \text { weeks }\end{array}$ & $\begin{array}{l}\text { - } 86 \% \\
\text { - } 82 \%\end{array}$ & yes \\
\hline $\begin{array}{l}\text { Langenbaek } \\
1976 \text { [48] }\end{array}$ & $\begin{array}{l}\text { CHX vs. } \\
\text { Placebo }\end{array}$ & $0.2 \%$ & $\begin{array}{l}1 \text { week } \\
2 \text { weeks } \\
3 \text { weeks }\end{array}$ & $\begin{array}{l}\text { - } 63 \% \\
\text { - } 57 \% \\
\text { - } 49 \%\end{array}$ & yes \\
\hline $\begin{array}{l}\text { Newman et } \\
\text { al. } 1981 \text { [46] }\end{array}$ & $\begin{array}{l}\text { CHX vs. } \\
\text { Placebo } \\
(\mathrm{NaCl})\end{array}$ & $0,2 \%$ & 1 week & - $37 \%$ & yes \\
\hline
\end{tabular}


Table 4. Reduction of BOP; $\mathrm{CHX}$ vs. placebo

\begin{tabular}{|c|c|c|c|c|c|}
\hline Author & $\begin{array}{l}\text { Rinsing } \\
\text { Agent }\end{array}$ & Concentration & Follow-up & $\begin{array}{l}\text { Mean BOP- reduction of } \\
\mathrm{CHX} \text { vs. Placebo }\end{array}$ & $\begin{array}{l}\text { Significant } \\
\text { reduction } \\
\text { (overall) }\end{array}$ \\
\hline $\begin{array}{l}\text { Sanz et al. } \\
1989 \text { [1] }\end{array}$ & $\begin{array}{l}\text { CHX vs. } \\
\text { Placebo }\end{array}$ & $0.12 \%$ & $\begin{array}{l}4 \text { weeks } \\
6 \text { weeks }\end{array}$ & $\begin{array}{l}\text { - } 41.6 \% \\
\text { - } 40 \%\end{array}$ & yes \\
\hline $\begin{array}{l}\text { Vaughan et } \\
\text { al. } 1989 \text { [47] }\end{array}$ & $\begin{array}{l}\text { CHX vs. } \\
\text { Placebo }\end{array}$ & $0.12 \%$ & $\begin{array}{l}1 \text { week } \\
2 \text { weeks }\end{array}$ & $\begin{array}{l}\text { - } 58 \% \\
\text { - } \quad 60 \%\end{array}$ & yes \\
\hline $\begin{array}{l}\text { Langenbaek } \\
1976[48]\end{array}$ & $\begin{array}{l}\text { CHX vs. } \\
\text { Placebo }\end{array}$ & $0.2 \%$ & $\begin{array}{l}1 \text { week } \\
2 \text { weeks } \\
3 \text { weeks }\end{array}$ & $\begin{array}{l}\text { - } 0 \% \\
\text { - } 10 \% \\
\text { - } 16 \%\end{array}$ & yes \\
\hline $\begin{array}{l}\text { Newman et } \\
\text { al. } 1981[46]\end{array}$ & $\begin{array}{l}\text { CHX vs. } \\
\text { Placebo } \\
(\mathrm{NaCl})\end{array}$ & $0.2 \%$ & 1 week & - $73 \%$ & yes \\
\hline
\end{tabular}


Table 5. Overview of included publications assessing the most beneficial $\mathrm{CHX}$-formulation.

\begin{tabular}{|c|c|c|c|c|c|c|c|}
\hline Author & $\begin{array}{l}\text { Rinsing } \\
\text { Agent }\end{array}$ & $\begin{array}{l}\text { Concentratio } \\
\mathrm{n}\end{array}$ & $\begin{array}{l}\text { Intervention } \\
\text { \& Duration }\end{array}$ & $\begin{array}{l}\text { Patient } \\
\text { No. }\end{array}$ & $\begin{array}{l}\text { Follow- } \\
\text { up }\end{array}$ & Evaluation & $\begin{array}{l}\text { Study } \\
\text { Design }\end{array}$ \\
\hline $\begin{array}{l}\text { Cortellini et } \\
\text { al. } 2008 \text { [50] }\end{array}$ & $\begin{array}{l}\text { CHX vs. } \\
\mathrm{CHX}+ \\
\text { ADS }\end{array}$ & $\begin{array}{l}0.2 \% \text { vs. } \\
0.2 \%+A D S\end{array}$ & $\begin{array}{l}\text { Open flap } \\
\text { debridement } \\
2 x / d \text { for } 1 \\
\text { week each } \\
\text { ( } 2 \text { weeks) }\end{array}$ & 47 & $\begin{array}{l}1,2 \\
\text { weeks }\end{array}$ & $\begin{array}{ll}\text { - } & \text { Gingival } \\
& \text { parameters } \\
\text { - } & \text { Staining } \\
\text { - } & \text { Patients } \\
& \text { acceptance }\end{array}$ & $\begin{array}{l}\text { Cross- } \\
\text { over } \\
\text { RCT }\end{array}$ \\
\hline $\begin{array}{l}\text { Bevilacqua et } \\
\text { al. } 2016 \text { [54] }\end{array}$ & $\begin{array}{l}\mathrm{CHX} \text { vs. } \\
\mathrm{CHX}+ \\
\text { ADS }\end{array}$ & $\begin{array}{l}0.12 \% \text { vs. } \\
0.2 \% \text { vs. } \\
0.2 \%+A D S\end{array}$ & $\begin{array}{l}\text { Open flap } \\
\text { debridement } \\
1 \text { week }\end{array}$ & 53 & $\begin{array}{l}1,2 \\
\text { weeks }\end{array}$ & $\begin{array}{ll}\text { - } & \text { Plaque Index } \\
\text { - } & \text { BOP } \\
\text { - } & \text { Staining } \\
\text { - } & \text { Patients } \\
& \text { acceptance }\end{array}$ & RCT \\
\hline $\begin{array}{l}\text { Genovesi et } \\
\text { al. } 2015 \\
{[28]}\end{array}$ & $\begin{array}{l}\text { CHX vs. } \\
\mathrm{CHX}+ \\
\text { hyaluro- } \\
\text { nic acid }\end{array}$ & $\begin{array}{l}0.12 \% \text { vs. } \\
0.12 \%+0.1 \% \\
\text { hyaluronic acid }\end{array}$ & $\begin{array}{l}\text { Implant } \\
\text { placement } \\
2 x / d \text { for } 15 \\
\text { days }\end{array}$ & 40 & $\begin{array}{l}3 \mathrm{~h}, 2 \mathrm{~d}, \\
15 \mathrm{~d}\end{array}$ & $\begin{array}{ll}\text { - } & \text { Plaque Index } \\
\text { - } & \text { BOP } \\
\text { - } & \text { Staining } \\
\text { - } & \text { Edema presence }\end{array}$ & RCT \\
\hline $\begin{array}{l}\text { Olsson et al. } \\
2012 \\
{[49]}\end{array}$ & $\begin{array}{l}\text { CHX vs. } \\
\text { alk-free } \\
\mathrm{CHX}\end{array}$ & $0.12 \%$ & $\begin{array}{l}\text { Open flap } \\
\text { debridement } \\
2 \text { weeks }\end{array}$ & 20 & $\begin{array}{l}2,4 \\
\text { weeks }\end{array}$ & $\begin{array}{ll}\text { - } & \text { Plaque Index } \\
\text { - } & \text { Patients } \\
& \text { acceptance }\end{array}$ & $\begin{array}{l}\text { Cross- } \\
\text { over } \\
\text { RCT }\end{array}$ \\
\hline $\begin{array}{l}\text { Duss et al. } \\
2010 \\
{[29]}\end{array}$ & $\begin{array}{l}\mathrm{CHX} \text { vs. } \\
\mathrm{CHX}+ \\
\text { herbal } \\
\text { extract }\end{array}$ & $\begin{array}{l}0,1 \% \mathrm{CHX} \\
\text { vs. } \\
0.05 \% \mathrm{CHX}+ \\
\text { herbal extract }\end{array}$ & $\begin{array}{l}\text { Open flap } \\
\text { debridem-ent } \\
4 \text { weeks }\end{array}$ & 45 & $\begin{array}{l}2,4,12 \\
\text { weeks }\end{array}$ & $\begin{array}{ll}\text { - } & \text { PPD } \\
\text { - } & \text { Staining } \\
\text { - } & \text { Bacteriological } \\
& \text { analysis }\end{array}$ & RCT \\
\hline $\begin{array}{l}\text { Laugisch et } \\
\text { al. } 2015 \text { [30] }\end{array}$ & $\begin{array}{l}\mathrm{CHX} \text { vs. } \\
\mathrm{CHX}+ \\
\text { herbal } \\
\text { extract }\end{array}$ & $\begin{array}{l}0,1 \% \mathrm{CHX} \\
\text { vs. } \\
0.05 \% \mathrm{CHX}+ \\
\text { herbal extract }\end{array}$ & $\begin{array}{l}\text { Flap surgery } \\
\text { for perio- } \\
\text { treatment or } \\
\text { Implant- } \\
\text { placement. } \\
2 x / d \text { for } 2 \\
\text { weeks }\end{array}$ & 40 & $\begin{array}{l}1,2 \\
\text { weeks }\end{array}$ & $\begin{array}{ll}\text { - } & \text { Early wound } \\
\text { healing } \\
\text { - } & \text { Staining } \\
\text { - } & \text { Patients } \\
\text { acceptance }\end{array}$ & RCT \\
\hline
\end{tabular}




\begin{tabular}{|l|l|l|l|l|l|l|l|}
\hline $\begin{array}{l}\text { Gkatzonis et } \\
\text { al. 2018 [61] }\end{array}$ & $\begin{array}{l}\text { CHX vs. } \\
\text { alk-free } \\
\text { CHX }\end{array}$ & $0.12 \%$ & $\begin{array}{l}\text { Open flap } \\
\text { debridement }\end{array}$ & 42 & 1,2 weeks & Early wound & RCT \\
vs. & & & & healing & Plaque Index \\
C31G & & & & & & Bacterial count \\
& & & & & & \\
\hline
\end{tabular}


Table 6. Plaque reduction after use of the different rinses.

\begin{tabular}{|c|c|c|c|c|c|c|}
\hline Author & $\begin{array}{l}\text { Rinsing } \\
\text { Agent }\end{array}$ & Concentration & $\begin{array}{l}\text { Patient } \\
\text { No. }\end{array}$ & Follow-up & $\begin{array}{l}\text { Plaque-reduction } \\
\text { compared to } \\
\text { baseline }\end{array}$ & $\begin{array}{l}\text { Significant } \\
\text { Difference } \\
\text { Between } \\
\text { Rinses }\end{array}$ \\
\hline $\begin{array}{l}\text { Bevilacqua } \\
\text { et al. } 2016 \\
{[54]}\end{array}$ & $\begin{array}{l}\text { CHX vs. } \\
\mathrm{CHX}+ \\
\text { ADS }\end{array}$ & $\begin{array}{l}\text { a. } 0.12 \% \\
\text { b. } 0.2 \% \\
\text { c. } 0.2 \%+ \\
\text { ADS }\end{array}$ & 53 & $\begin{array}{l}1 \text { week } \\
2 \text { weeks }\end{array}$ & $\begin{array}{ll}\text { a. } & 4.8 \% \\
\text { b. } & 3.9 \% \\
\text { c. } & 3.8 \% \\
\text { a. } & 3.7 \% \\
\text { b. } 3.9 \% \\
\text { c. } 1.2 \%\end{array}$ & $\begin{array}{l}\text { No statistical } \\
\text { difference }\end{array}$ \\
\hline $\begin{array}{l}\text { Genovesi et } \\
\text { al. } 2015 \text { [28] }\end{array}$ & $\begin{array}{l}\text { CHX vs. } \\
\mathrm{CHX}+ \\
\text { hyaluronic } \\
\text { acid }\end{array}$ & $\begin{array}{ll}\text { a. } & 0.12 \% \\
\text { b. } & 0.12 \%+ \\
& 0.1 \% \\
& \text { hyaluronic } \\
& \text { acid }\end{array}$ & 40 & 2 weeks & $\begin{array}{l}\text { a. } 16 \% \\
\text { b. } 22 \%\end{array}$ & $\begin{array}{l}\text { No statistical } \\
\text { difference }\end{array}$ \\
\hline $\begin{array}{l}\text { Olsson et al. } \\
2012 \text { [49] }\end{array}$ & $\begin{array}{l}\text { CHX vs. } \\
\text { alk.-free } \\
\mathrm{CHX}\end{array}$ & $\begin{array}{ll}\text { a. } & 0,12 \% \\
\text { b. } & 0.12 \% \\
& \text { without Alk. }\end{array}$ & 20 & $\begin{array}{l}2 \text { weeks } \\
4 \text { weeks }\end{array}$ & $\begin{array}{l}\text { no baseline score } \\
\text { assessed }\end{array}$ & $\begin{array}{l}\text { No statistical } \\
\text { difference }\end{array}$ \\
\hline $\begin{array}{l}\text { Gkatzonis et } \\
\text { al. } 2018 \text { [61] }\end{array}$ & $\begin{array}{l}\text { alk.-free } \\
\mathrm{CHX} \\
\text { vs. } \mathrm{CHX}\end{array}$ & $\begin{array}{l}\text { a. } 0.12 \% \\
\text { b. } 0.12 \%\end{array}$ & 42 & $\begin{array}{l}1 \text { week } \\
2 \text { weeks }\end{array}$ & $\begin{array}{l}\text { No baseline score } \\
\text { assessed }\end{array}$ & $\begin{array}{l}\text { Statistical } \\
\text { significant }\end{array}$ \\
\hline
\end{tabular}


Table 7. Mean stain reduction; test rinses vs. control rinses.

\begin{tabular}{|c|c|c|c|c|c|c|}
\hline Author & $\begin{array}{l}\text { Rinsing } \\
\text { Agent }\end{array}$ & Concentration & $\begin{array}{l}\text { Patient } \\
\text { No. }\end{array}$ & Follow-up & $\begin{array}{l}\text { Mean reduction of } \\
\text { staining in the test group }\end{array}$ & $\begin{array}{l}\text { Significant } \\
\text { Reduction } \\
\text { (overall) }\end{array}$ \\
\hline $\begin{array}{l}\text { Cortellini et } \\
\text { al. } 2008 \text { [50] }\end{array}$ & $\begin{array}{l}\text { CHX vs. } \\
\mathrm{CHX}+ \\
\text { ADS }\end{array}$ & $\begin{array}{l}0.2 \% \text { vs. } \\
0.2 \%+A D S\end{array}$ & 47 & $\begin{array}{l}1 \text { week } \\
2 \text { weeks }\end{array}$ & $\begin{array}{l}\text { - } 52 \% \\
\text { - } 37 \%\end{array}$ & yes \\
\hline $\begin{array}{l}\text { Bevilacqua } \\
\text { et al. } 2016 \\
\text { [46] }\end{array}$ & $\begin{array}{l}\text { CHX vs. } \\
\mathrm{CHX}+ \\
\text { ADS }\end{array}$ & $\begin{array}{l}0.12 \% \text { vs. } \\
0.2 \% \text { vs. } \\
0.2 \%+A D S\end{array}$ & 53 & 1,2 weeks & $\begin{array}{l}\text { No percentage } \\
\text { value calculable }\end{array}$ & no \\
\hline $\begin{array}{l}\text { Genovesi et } \\
\text { al. } 2015 \text { [28] }\end{array}$ & $\begin{array}{l}\text { CHX vs. } \\
\mathrm{CHX}+ \\
\text { hyaluroni } \\
\text { c acid }\end{array}$ & $\begin{array}{l}0.12 \% \text { vs. } \\
0.12 \%+0.1 \% \\
\text { hyaluronic acid }\end{array}$ & 40 & 2 weeks & - $12 \%$ & no \\
\hline $\begin{array}{l}\text { Duss et al. } \\
2010[29]\end{array}$ & $\begin{array}{l}\text { CHX vs. } \\
\mathrm{CHX}+ \\
\text { herbal } \\
\text { extract }\end{array}$ & $\begin{array}{l}0,1 \% \mathrm{CHX} \\
\text { vs. } \\
0.05 \% \mathrm{CHX}+ \\
\text { herbal extract }\end{array}$ & 45 & 4 weeks & - $21.1 \%$ & yes \\
\hline $\begin{array}{l}\text { Laugisch et } \\
\text { al. } 2015 \text { [30] }\end{array}$ & $\begin{array}{l}\text { CHX vs. } \\
\mathrm{CHX}+ \\
\text { herbal } \\
\text { extract }\end{array}$ & $\begin{array}{l}0,1 \% \mathrm{CHX} \\
\text { vs. } \\
0.05 \% \mathrm{CHX}+ \\
\text { herbal extract }\end{array}$ & 40 & $\begin{array}{l}1 \text { week } \\
2 \text { weeks }\end{array}$ & $\begin{array}{l}\text { - } 5 \% \\
\text { - } 11 \%\end{array}$ & no \\
\hline
\end{tabular}

